\title{
Erotismo dançante e as distâncias sociais entre homens e mulheres no Brasil
}

\author{
Dancing eroticism and the social distances between men and \\ women in Brazil
}

Fernando de Jesus Rodrigues ${ }^{1}$ e Letícia Souza ${ }^{2}$

\begin{abstract}
Resumo: Quais questões humanas estão envolvidas no sucesso e nas reações ao sucesso de gêneros musicais e danças, surgidas nas "periferias" de cidades brasileiras a partir dos anos 90? Um dos interesses desse artigo é refletir sobre aspectos que contribuíram para a formação de campos de aproximação e distanciamento entre homens e mulheres, jovens e adultos a partir do final do século XX no Brasil. Preocupamos com a diferenciação de emoções, práticas e jogos simbólicos eróticodançantes. Particularmente, na direção das músicas e danças que, em letras e gestos, trazem para a dimensão dos símbolos representações de atos de coito e de sedução explicitamente erótico-sexuais em espaços públicos direta ou indiretamente mercantilizados.
\end{abstract}

Palavras-chave: erotismo dançante, distância social, emoções

\footnotetext{
1 Professor do Instituto de Ciências Sociais e do Programa de Pósgraduação em Sociologia da Universidade Federal de Alagoas. Líder do GRUPPAES (Grupo de Pesquisa Periferias, Afetos e Economias das Simbolizações). E-mail: ferssa@gmail.com

${ }^{2}$ Mestranda do Programa de Pós-graduação em Sociologia da Universidade Federal de Alagoas. Integrante do GRUPPAES (Grupo de Pesquisa Periferias, Afetos e Economias das Simbolizações). E-mail: leh.ufal@hotmail.com
} 


\title{
Erotismo dançante e as distâncias sociais entre homens e mulheres no Brasil
}

\begin{abstract}
Which human problems connect with the success or with reaction to success of musical genres and dances that came out in Brazilian urban "peripheries" from nineties? One of our interests is to reflect on aspects that contributed to build proximity and distance fields among men and women, young and adults from the end of $20^{\text {th }}$ century. We are worried about on differentiation of erotic dancing gestures and emotions, expressed in music and dances that represent acts of sex or seduction in monetized public spaces.
\end{abstract}

Keywords: dancing eroticism, social distance, emotions

\footnotetext{
“Se, de um lado, o eu se entrega inteiramente a uma impressão momentânea, sendo por ela "possuído"; se, de outro, há maior tensão entre o sujeito e seu objeto, o mundo exterior; se a realidade externa não é simplesmente contemplada e percebida, mas se acomete o homem repentina e imediatamente, no afeto do medo ou da esperança, do terror ou dos desejos satisfeitos e libertos, então, de alguma forma salta a faísca: a tensão diminui a partir do momento em que a excitação subjetiva se objetiva, ao se apresentar perante o homem como um deus ou um demônio." (Ernst Cassirer,

Linguagem e Mito)
}

Parece ser importante, ainda, defender a ideia de que músicas e danças como divertimentos são fenômenos tão relevantes para se compreender direções das redes humanas quanto outros diretamente relacionados à política, à economia ou à religião. $\mathrm{Na}$ experiência de formação do nível de integração nacional brasileiro, as referências tanto às mulheres, através de figuras estereotipadas como "a baiana" (BALIEIRO, 2015; MACEDO, 2011) ou "a mulata" (CORREA, 1996; GILLIAM, GILLIAM, 1995; GILLIAM, 1998), quanto às músicas, como o samba e o baião (SEVERIANO, 2008), serviram de sinais dos vínculos entre estratos de homens e mulheres no Brasil do século XX expressos em linguagens como as danças.

Entretanto, se as músicas e os músicos foram um dos focos principais do interesse de diferentes linhagens de 
pesquisadores, assim como as festas populares nas quais se apresentavam as músicas populares, porque as danças relacionadas a essas expressões não despertaram o mesmo interesse para se compreender as formas de integração ou desintegração nacional-brasileira?

$O$ interesse pela dança durante o século $X X$ ficou reservado aos folcloristas, antropólogos e aos pesquisadores da educação e das artes cênicas, especialmente da etnocenologia (ANDRADE, 1982; MONTEIRO, 2011; GIFFONI, 1955). Entretanto, no caso dos últimos, mantiveram-se distantes da problemática da integração/desintegração nacional. Ademais, tratar da dança traria outro assunto celebrado na tradição nacional-brasileira de sentimentos mas ausente no repertório do pensamento social brasileiro do século $X X$ : o papel das mulheres e, de modo complementar, dos homens, em situações de divertimento "popular" cujas ambiências ganhavam forma a partir de símbolos musicais-dançantes com sentido eróticos. É emblemático a esse respeito, seguindo as pistas de Fernandes (2014) e Napolitano (2007), a maneira como críticos musicais em revistas legislaram o que seria próprio e impróprio para integrar a cultura brasileira nos anos 40 do século XX. Tratando do samba, Renato Alencar, locutor da Rádio Nacional defendia:

O samba é um dos ramos das danças importadas com o tráfico negreiro e que se fixou e evolucionou entre nós (...) Divide-se em duas classes: o samba de morro, a batucada, dança litúrgica bárbara e sensual (...) não tem beleza nenhuma, é monótono e triste como todo produto de povos torturados e incultos; o outro é o samba de arte, suportado no salão e no teatro nutrido pela influência dos mais altos pendores líricos (...) dessa forma, há uma espécie de samba que pode levar, sem receio, a etiqueta 


\section{Erotismo dançante e as distâncias sociais entre homens e mulheres no Brasil}

made in Brazil (Apud NAPOLITANO, 2007, p. 42)

No trecho, podemos depreender uma balança de sentidos que direcionava o critério de seletividade de gestos associados ao samba que receberiam a etiqueta "made in Brazil". De um lado o lírico, marca de propensão à beleza poéticoliterária, a arte, polo de inclusão, opondo-se à sensualidade, associada à dança, rotulada como bárbara, significando desvalorização e polo de exclusão. Tal balança de sentidos lírico "versus" sensual, o primeiro como polo positivo e o segundo como negativo - expressava uma estrutura normativa que não era nova. Ela podia ser observada na relação entre estratos mais poderosos e menos poderosos que, de alguma forma, estavam constrangidos a buscar uma linguagem de integração frente às pressões para aproximações psíquicosociais entre homens e mulheres, livre, libertos e escravos, desde o início do século XIX, expressa nas tensões entre a modinha e o lundu (TINHORÃO, 2004; SALLES, 2005; SANDRONI, 2001; DEL PRIORE, 2013;). Entretanto, tal processo de aproximação ganhou uma nova intensidade com a abolição da escravidão no final do século XIX com o sucesso do maxixe (VELOSO, 2007). Jota Efegê, tratando do desenvolvimento do maxixe como dança desde os anos 1880, especialmente do curso que o fez chegar à Paris e aos salões de famílias aristocráticas brasileiras entre os anos 10 e 30 do século $X X$, deixa muitas pistas para se pensar um processo de disciplinamento ou formalização nacional do erótico encarnado no declínio do maxixe e incrustado na ascensão do samba. $\mathrm{O}$ jornalista e crítico carioca relata a repercussão da aceitação do maxixe em Paris, pelas mãos de Duque, um dançarino que teria transformado a dança em uma expressão "civilizada", deixando-a irreconhecível quanto ao estilo "popular" de deixar "quebrar a maxixada, livre, à vontade": 
Fernando de Jesus Rodrigues e Letícia Souza

Pródiga na louvação, Sylvia de Leon não sopitou o deslumbramento que lhe causou o maxixe, elegante, aristocrático, na concepção com que Duque burilando-o, livrara-o do anátema de indecente, de anti-familiar .

Mas, não era aquela a autêntica dança do maxixe. A coreografia que merecera tão farta louvação nada tinha que fizesse lembrar a sua origem, ou seja, o desempenho de passos, de pernadas e, principalmente, do rebolamento com que no longínquo 1880 era quebrado na "Primeira Sociedade do Catete!!! (nunca omitindo as três exclamações)"

Naquele remoto fandango em que as maxixeiras tiveram "capilé e maduro à farta", a preocupação de elegância, do trajar puxado a casaca e a vestido longo, assim como os volteios e requebros graciosos, nem sequer passaram pela cabeça dos dançarinos. O que importava era quebrar a maxixada, livre, à vontade.

Com o correr do tempo, perdendo seu fastígio, pois o samba, na generalidade com o que se qualificava a nossa música popular, o ia substituindo facilmente, o maxixe, aos poucos foi sendo esquecido. A geração que surgia, quando não o ignorava tinha dele apenas escassas informações. A moda era dançar o samba, buliçoso, convidativo, mas sem os arroubos rebolantes do maxixe. (EFEGÊ, 2009, p.59, grifos meus)

Do trecho, destaca-se a ênfase de Efegê na perda dos movimentos "rebolantes" do maxixe no curso que o levou da 


\section{Erotismo dançante e as distâncias sociais entre homens e mulheres no Brasil}

"Primeira Sociedade do Catete", em 1880, uma associação de dança "popular", até salões aristocráticos do Rio de Janeiro, nos anos 1920. No mesmo movimento, expressões e nomes identificados como "populares" interpenetraram-se a formações sentimentais e códigos normativos da "boa sociedade" carioca sob avaliações prestigiosas. Ademais, no mesmo curso de desenvolvimento de mútuas transformações entre expressões "populares" e "aristocráticas", ganha proeminência o samba. Tal interpenetração mostrou suas ambivalências para aqueles que experimentaram as delícias emocionais vindas dos gestos dançantes do maxixe do passado. De um lado, os setores abastados adotaram a moda de "dançar o samba, buliçoso, convidativo, mas sem os arroubos rebolantes do maxixe", de outro. Parece plausível destacar que há um desenvolvimento de equilíbrios de tensões entre formações sentimentais e normativas expressas na "civilização do maxixe" e na ascensão do samba que coloca as funções afetivas de matiz erótico como focos da discussão acerca da imagem de grupo nacionalbrasileira.

Os trechos referem-se a dois momentos de um período de desenvolvimento das danças no Brasil, entrelaçado ao processo de centralização política e econômica, incluindo seus vínculos com os divertimentos, entre os anos 1880 e 1945. Deles, pode-se depreender que um dos critérios de nacionalização dos sentimentos e das práticas populares defendido por setores dominantes da crítica cultural em revistas, jornais e rádios esteve relacionado à restrição de representações de gestos erótico-dançantes e a abertura para a difusão da música e da letra poético-literária de setores "populares". Para além da questão étnico-racial, predominantemente abordada, a divisão social dos estilos de erotismo "popular" e, ainda que não nomeado, aquela expressa pelos diferentes "erotismos" de diferentes estratos de mulheres, mostra-se um problema relevante para se pensar os critérios de seletividade que 
compuseram estruturas normativas como a expressa na imagem-de-grupo nacional popular brasileira. As posições dos grupos que podiam concentrar o poder de selecionar gestos e nomes para expressar tal representação coletiva eram homólogas àquelas do mundo intelectual próximas dos setores que detinham crescente poder político e simbólico no curso da centralização estatal expressa na figura de Getúlio Vargas.

Isso parece ter contribuído para sombrear cursos de integração social efetivamente existentes entre homens e mulheres, expressos em instituições associadas a economias do divertimento musical-dançante, tais como o circo, o teatro de revista, a radionovela, o cassino, a chanchada, a pornochanchada, a telenovela, o programa de auditório, além do filme erótico e pornográfico.

No caso da música, tal filtro contribuiu para uma pressão por "periferizar" representações de músicas com funções prioritariamente erótico-dançantes como o baião e o maxixe. O samba foi celebrado no Brasil, antes de tudo como música, não como dança. A visão do Brasil como lugar de liberdades eróticas-sexuais sem limites é amplamente disseminada internacionalmente mas, de alguma forma, os abastados culturais brasileiros simplesmente silenciam sobre esta pressão simbólica "externa". Em outros termos, apesar de compor a formação sentimental de largos estratos sociais brasileiros, as expressões erótico-dançantes foram mantidas a certa distância da avaliação normativa prestigiosa que vinha formando a imagem de grupo nacional. As distâncias entre as formações sentimentais e normativas parecem ser uteis para compreender os níveis e as direções de integração sócio afetivas de uma rede humana. Quanto maior a distância entre experiência e norma, maior a hipocrisia e o recurso à violência física. Tal padrão de brutalidade decorre da necessidade de setores que concentram poderes de ranqueamento social para reprimir a visibilidade de expressões afetivas aparentemente 


\section{Erotismo dançante e as distâncias sociais entre homens e mulheres no Brasil}

contrárias aos ideais de regulação da vida defendido por eles. Tal questão ajuda-nos a ter uma visão sobre o desenvolvimento e a qualidade da integração de uma rede humana.

É curioso notar, a esse respeito, que o baião tenha sido solenemente ignorado em periódicos que buscaram legislar sobre o significado da música popular brasileira, como a Revista da Música Popular, publicada na segunda metade dos anos 50 (ALVES, 2012), apesar de o baião ter tido uma enorme importância no processo de nacionalização de símbolos e experiências dos setores populares dos anos 40 e 50. Também nesse sentido, parece interessante explorar as razões da ambivalência do tipo de reconhecimento conferido a Ernesto Nazareth, músico brasileiro. Ainda que ele tenha ambicionado reconhecer-se um músico erudito nos termos da música europeia de concerto, foi prioritariamente celebrado pelo desenvolvimento que deu a polca, especialmente a polcamaxixe, um gênero visto como menor pelos críticos da época, desenvolvido em salões, onde explorou a sincopa, cultivada, em grande medida, em situações dançantes brasileiras como salões e cineteatros, não salas de concerto (MACHADO, 2007).

Assim, a relação entre integração popular-nacional e cultura do divertimento foi enfocada privilegiadamente em torno de figuras e funções associadas a tradições masculinas tais como a elaboração das letras e a execução das músicas. As funções eróticas mais associadas às mulheres e ao universo feminino como a interpretação de músicas e a expressão de danças não tiveram a mesma atenção. Tal lacuna parece dificultar a compreensão das dinâmicas intergeracionais que nos trouxeram até o mundo contemporâneo brasileiro. Neste curso, parcelas dos prazeres e frustrações e, correlatamente, dos jogos de poder, gravitam em torno do erotismo-dançante, repercutindo nas relações entre homens e mulheres, jovens e adultos, oriundos de diferentes regiões do país. 
A partir dos anos 90 do século XX ficou mais nítida a diferenciação de forças de avaliação humana crescentemente públicas e sexualizadas expressas em músicas e danças tais como a swingueira (pagode baiano, axé) (MOURA, 1996; NASCIMENTO, 2012; RODRIGUES, 2016a), o funk (VIANNA 1997, HERSCMANN 1997; 2000, HERSCHMANN E FREIRE FILHO 2003, VELHO E ALVITO 2000, ZALUAR E ALVITO 1997, ESSINGER 2005), o tecnobrega (LEMOS, 2008; SILVA, 2009; RODRIGUES, 2016b) e o reggae e as discotecas em Maceió, Alagoas (RODRIGUES, 2017), entre outros gêneros que surgiram em intensidades inéditas nas "periferias" de cidades brasileiras de norte a sul. O surgimento e o sucesso de muitos desses gêneros acabaram por atrair forças contrárias de depreciação e estigmatização, formando campos de complementaridades e repulsas. Um exemplo de força de depreciação foi a criação de uma página no site facebook intitulada "funk é lixo", criada por um microempresário de São Paulo que também propôs um projeto de lei que pretende "criminalizar o funk". Tal projeto chegou ao senado e aguarda relatoria, já designada. Tais forças também surgiram quando do estrondoso sucesso do grupo “É o Tchan!" nos anos 90 e 2000, despertando calorosas controvérsias sobre a visibilidade dos movimentos de bumbum e as expressões de sensualidade.

Uma pergunta que parece relevante diante desses eventos é: quais questões humanas estão envolvidas no sucesso e nas reações ao sucesso desses gêneros surgidos nas "periferias" de cidades brasileiras? Um dos interesses desse artigo é refletir sobre aspectos que contribuíram para a formação de campos de aproximação e distanciamento entre homens e mulheres, jovens e adultos no Brasil do século XX e início do XXI, através da diferenciação de emoções, práticas e jogos simbólicos erótico-dançantes. Particularmente, na direção das músicas e danças que, em letras e gestos, trazem para a dimensão dos símbolos representações de atos de coito e de 


\section{Erotismo dançante e as distâncias sociais entre homens e mulheres no Brasil}

sedução explicitamente erótico-sexuais em espaços públicos direta ou indiretamente mercantilizados.

\section{Instrumentais de investigação de processos expressivos}

Para entender o aumento da importância das formas de expressão erótico-dançantes nas relações entre homens e mulheres no Brasil, é importante assinalar que se trata de um processo ao mesmo tempo social e psíquico. Parto da concepção de que ele depende de três aspectos do desenvolvimento humano: da maneira como grupos sociais são capazes de controlar a natureza, incluindo as doenças e a fome, reduzindo as incertezas advindas da relação com o mundo não-humano, assim como depende das formas de controle dos homens uns sobre os outros e das formas específicas de autocontrole. Tais aspectos se desenvolvem entrelaçadamente. Trata-se da tríade que Wouters (2014) ressalta como estando na base da teoria dos processos civilizadores de Norbert Elias (1998). A direção de um processo psíquico-social depende dos estágios específicos em que se encontram os grupos humanos quanto ao controle dos conflitos e incertezas vindas: da relação com a natureza, da relação dos homens entre si e da relação dos indivíduos com eles próprios, aprendidos socialmente (ELIAS, 2011).

Para "medir" as direções de desenvolvimento dessa tríade em determinados cursos sociais, valho-me também de instrumentos auxiliares relacionados a mesma teoria dos processos civilizadores. A partir deles, pode-se lidar com diferentes níveis de integração entre pessoas e suas redes, níveis estes que podem ser compreendidos através de tipos de balanças sociais ou ainda, como equilíbrios de tensões entre indivíduos e grupos.

No caso do processo de intensificação da sexualização erótico-dançante expresso no surgimento de vários gêneros de 
músicas e danças de norte a sul do Brasil, exploraremos aspectos do curso de hábitos e costumes a partir do destaque sobre o equilíbrio de controles, o equilíbrio dos desejos e o equilíbrio entre as formas de identificação eu-nós. No primeiro equilíbrio, temos as maneiras como os controles externos se tencionam com os autocontroles; no segundo, as formas das tensões emocionais vindas de intimidades eróticas expressas em termos de um polo amor ou um polo sexo; por fim, os equilíbrios relacionados às forças emotivas mais pendentes a se expressarem em termos de imagens de grupos ou de imagens de eu, algo que se expressa em outra balança, a da centralização e centrifugação das relações sociais em um território, também expressa pela polarização região-nação.

Em alguns sentidos específicos, argumentamos que há uma redução das distâncias psíquicas e sociais entre homens e mulheres, assim como entre diferentes estratos sociais no Brasil. Tal argumentação não implica jogar para debaixo do tapete as engrenagens de reprodução das distâncias sociais e das formas de violência relacionadas a elas no Brasil. No entanto, a percepção de tais forças também não deveria obliterar a vista de fenômenos que podem ser bem representados como expressando diminuição das desigualdade de poder em determinados âmbitos da vida, como a liberdade de expressão erótica pública, sem retaliações. Ademais, que a observância de maiores conflitos públicos, no âmbito das opiniões e julgamentos em mídias sociais, é mais uma evidência de redução das distâncias de poder entre grupos sociais frente ao anterior silêncio imposto sob uma balança muito mais desequilibradamente desigual. Muitas vezes, a exposição do conflito público, ainda que expressando fortes cargas de intolerância e violência, expressa a ousadia dos anteriormente mais fracos para ingressarem em batalhas públicas de opinião. Tais exposições favorecem o aumento da ansiedade social disseminada entre os diferentes grupos, logo, de maior 
Erotismo dançante e as distâncias sociais entre homens e mulheres no Brasil

sofrimento psíquico, mas provavelmente, também expressa uma redução das desigualdades de poder (ELIAS, 2006; WOUTERS, 2004).

Redução do medo da fome e da morte e a ampliação de linguagens musicais, dançantes e eróticas

Um aspecto do problema se refere a diferenciação ampliadora de expressões musicais, dançantes e eróticas ser um desenvolvimento de repertórios simbólicos. Tal movimento requer que uma parte importante da população deixe de estar primordialmente premida pelas incertezas vindas da fome e das doenças, propiciando gradientes maiores de separação entre dependências afetivas domésticas e extra domésticas. É curioso notar, nesse sentido, que a expansão de gestos musicais e dançantes, com sentidos erótico-sexuais, ser uma ampliação de um repertório social de linguagens que ligam indivíduos em uma cadeia mais extensa. Trata-se de um desenvolvimento ampliador da cultura, ainda que tal afirmação soe estranha para muitos grupos "eruditos". Mas mostra-se congruente com a percepção de que tais linguagens se desdobraram, espalhando sua importância pelos mais diferentes setores pobres, adultos e jovens, homens e mulheres, além de diferentes regiões do país nos últimos 50 anos no mesmo curso social que engendra outros processos como as reduções da fecundidade e da mortalidade infantil (DUARTE, 2007) além do aumento da expectativa de vida como podemos ver nos gráficos abaixo. 
Fernando de Jesus Rodrigues e Letícia Souza

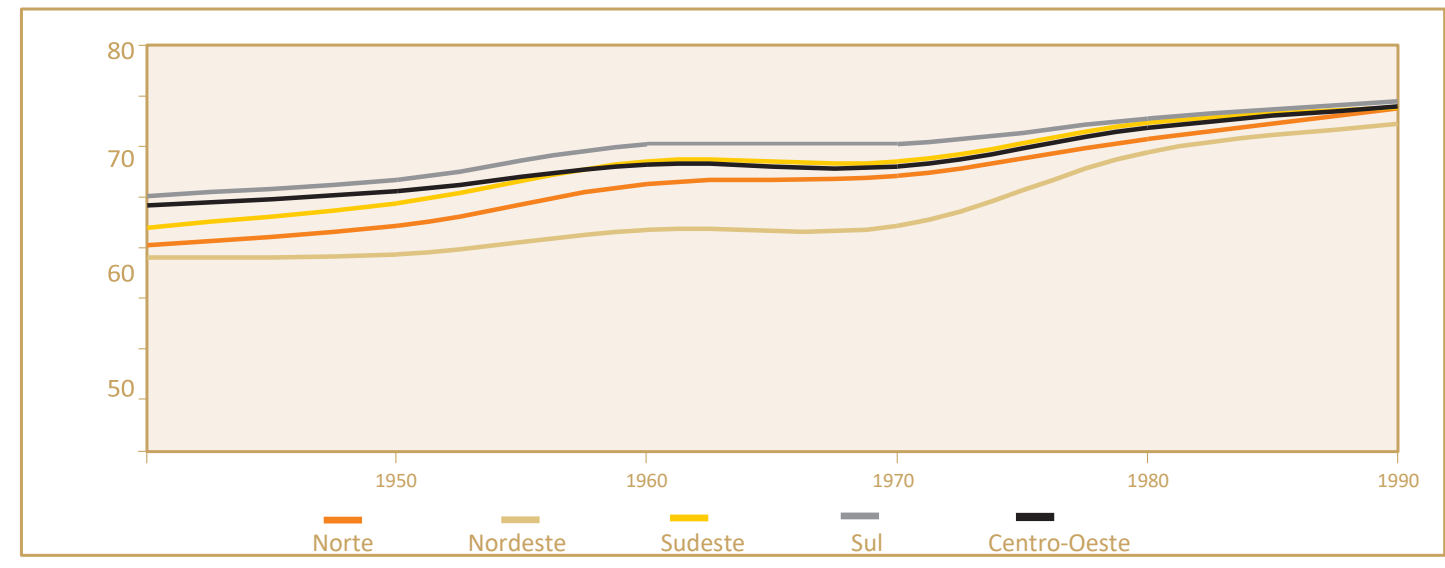

Gráfico 1 - Evolução da esperança de vida ao nascer, por Grandes Regiões - Brasil 1940/1990

Fonte: Anuário estatístico do Brasil 1990. Rio de Janeiro: IBGE, v. 50, 1990, apud Estatísticas brasileiras do século XX, 2006.

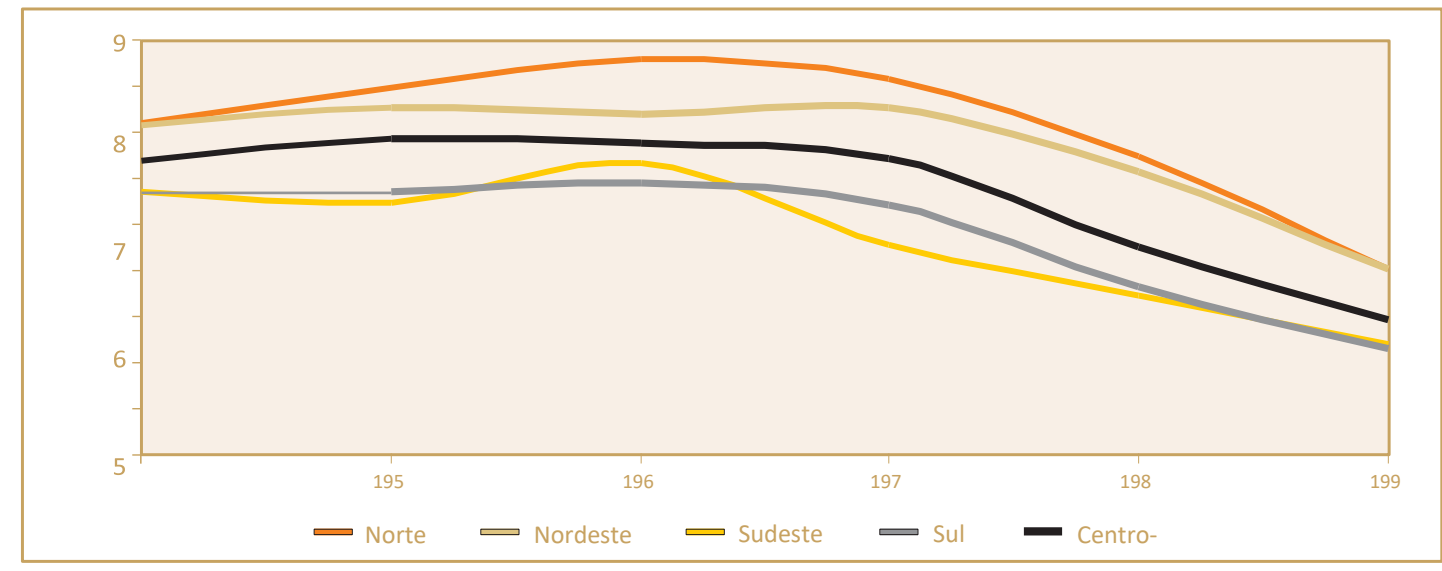

Gráfico 2 - Evolução da taxa de fecundidade total, por Grandes Regiões Brasil -1940/1990

Fonte: Anuário estatístico do Brasil 1998. Rio de Janeiro: IBGE, v. 58, 1999, apud Estatísticas brasileiras do século XX, 2006.

Dos gráficos, vê-se que ao longo de 50 anos, a expectativa de vida foi crescente em todas as regiões do país. Destaca-se, entretanto, a redução das distâncias entre as regiões. 


\section{Erotismo dançante e as distâncias sociais entre homens e mulheres no Brasil}

De uma diferença de 12 anos em favor da região Sul contra o Nordeste nos anos 40, ela reduz-se a 4,4 anos nos anos 90, entre as mesmas regiões. Em linguagem percentual, a diferença caiu algo em torno de $63 \%$. Chama a atenção também o período de mais forte redução das desigualdades na série: o final dos anos 70 e início dos anos 80. Adicionalmente, de acordo com relatório da FAO-Brasil de 2015, o Brasil, entre 2004 e 2012 havia reduzido em $82 \%$ a população que passava fome entre 2004 e 2014, reduzindo a 5\% a população total que se encontrava nesta condição (O ESTADO DA SEGURANÇA ALIMENTAR E NUTRICIONAL NO BRASIL, 2015). A ministra do desenvolvimento social da época alardeou que o Brasil conhecia a primeira geração de crianças que não havia conhecido a fome.

Ademais, em estudo que visou compreender aspectos da evolução dos padrões de consumo e relações com a distribuição de renda, a partir das Pesquisas de Orçamentos Familiares (POF) de 2003 e de 2009, destaca-se uma conclusão:

\footnotetext{
Relativamente, a maior transformação ocorreu justamente no padrão de consumo das famílias mais pobres, que beneficiadas pela alta valorização da renda puderam reduzir a parcela de seus gastos essenciais com alimentação doméstica e diversificar seu padrão de consumo, passando a consumir bens e serviços. (DÓRIA, 2013, p. 84)
}

Disso tudo, destaca-se que apenas após os anos 80 do século XX, o Brasil conhece condições "universais" de redução do medo da fome e da mortalidade infantil entre os grupos mais pobres de diferentes regiões do país, aumentando-se as valências direcionadas para o consumo de bens e serviços simbólicos. Eis a novidade, durante as quatro últimas décadas: 
a ideia de pobreza se distanciou relativamente da fome e da mortalidade infantil. Isso parece congruente com a emergência de novos, diversificados e mais amplos campos de complementaridades e conflitos culturais como os expressos em congregações religiosas, escolas, universidades, mas também em bailes e discotecas através de gêneros musicais e dançantes entre os mais pobres.

Tal surto de ampliação da diversidade expressiva entre os pobres parece expressar a liberação de valências afetivas para novas formas de gratificação e luta, decorrentes das relações das pessoas entre si. Abriu-se novas dimensões simbólicas para os mais pobres sob estruturas de vida urbana crescentemente monetarizadas, nacionalizadas e internacionalizadas. Muitas delas vieram sob a forma de lutas por honra associadas ao sentimento de ter um trabalho formal, pertencer a uma congregação religiosa ou sentir-se superior pelo poder armado ou pela capacidade de consumo e apresentação de bens. Tudo isso entrelaçou-se a conflitos e complementaridades amoroso-sexuais revestidos de camadas simbólicas musicais-dançantes.

Assim, não parece sem sentido que algumas cidades e regiões a partir dos anos 90, outras a partir dos 2000, tenham experimentado uma intensificação do consumo de divertimentos que estimulam ambiências erótico-dançantes. Tal movimento contribuiu para a alteração não apenas das relações de procura por diversões com funções eróticas entre homens e mulheres jovens mas também entre mulheres e homens mais velhos. Incluindo relações nas quais mulheres passaram a consumir, ao longo do casamento, bebidas alcoólicas, a frequentar festas ou, uma vez separadas, a paquerar abertamente, além de buscar relações sexuais "livres", quando, em suas adolescências e primeira fase adulta isso seria considerado uma grande barreira social para ter boa reputação. 


\section{Erotismo dançante e as distâncias sociais entre homens e mulheres no Brasil}

A juvenilização do divertimento veio com um movimento de transformação das fronteiras de status entre as mulheres mais velhas e mais jovens quanto aos seus valores no mercado de namoros e casamentos, repercutindo mutuamente no ranking dos homens mais jovens e mais velhos. As oportunidades de as mulheres experimentarem abertamente flertes, intimidades eróticas, sexo e namoros antes do casamento se ampliou de tal forma que houve uma redução das distâncias sociais entre a "mulher pra casar" e a "mulher pra curtir", a "santinha" e a danadinha", a bem e a má-reputada. Em uma via complementar e conflitiva, borraram-se as fronteiras de status dos homens, flexibilizando os limites de reconhecimento entre o "provedor" e o "gingolô", entre o "trabalhador" e o "cachaceiro", entre o "companheiro" e o "amante" ou entre o "canalha" e o "homem de bem".

Os sentimentos e os rankings sociais de homens e mulheres ficaram mais ambivalentes e instáveis. De maneira entrelaçada, desenvolveram-se tipos de normatizações mais heterogêneos e conflitivos entre si, expressão da ampliação de múltiplas complementaridades e oposições entre aliados e adversários no mundo das opiniões e julgamentos. Assim, entrelaça-se a redução dos medos da fome e da morte entre os setores mais pobres e a ampliação dos campos de gratificação e repulsas em torno de linguagens erótico-dançantes "brasileiras" a partir dos anos 90, assim como espaços de julgamentos públicos dessas linguagens. Sob condições específicas do estágio de distanciamento dos medos da morte e de doenças "biológicas" e "ambientais", parece que houve uma ampliação de novos e diversificados repertórios de símbolos tanto religiosos quanto eróticos entre os mais pobres do Brasil. Os símbolos com que amplos setores da sociedade passaram a viver o tempo da vida alteraram-se, assim como a qualidade das camadas de linguagem com que passamos a medir 
distâncias e proximidades sociais entre diferentes segmentos humanos, como homens e mulheres, jovens e adultos.

\section{A redução das distâncias entre homens e mulheres e a ampliação de espaços erótico-dançantes}

Conheci o meu marido em minha casa, ele era amigo dos meus pais. Ele era 25 anos mais velho que eu. Não foi um casamento que eu escolhi. Escolheram pra mim, [...] meu pai e meu irmão. Ele era uma pessoa separada a mais de 12 anos, convivia com minha família e papai decidiu que eu ia casar com ele. E eu casei com ele. É difícil. [...] Eu não podia dizer não. [...] É terrível... Hoje, graças a Deus, meus filhos tem livre arbítrio. (Mulher, funcionária pública municipal, 59 anos, migrou do interior de Alagoas para Maceió nos anos 80, entrevista concedida ao autor)

O trecho expõe uma trajetória de aproximação de um homem e uma mulher que não pode ser considerada incomum. Nele destaca-se a obediência à regra "patriarcal" da troca de parentesco, na qual o pai ou a autoridade máxima familiar (em alguns casos pode ser o irmão mais velho ou uma mulher, quando viúva) tem o poder de selar um acordo matrimonial com outra autoridade familiar, cabendo-lhes a responsabilidade pela escolha do(a)s parceiro(a)s dos filhos. Algo soa surpreendente pelo ano em que tal "regra" ainda vigia: 1974. No entanto, a surpresa expõe o desconhecimento de determinados segmentos urbanos de regiões metropolitanas, de renda média e alta, sobre as condições de integração social de um país e uma nação, sobre a vida emocional dos mais pobres e dos interioranos dos "sertões" brasileiros (REBHUN, 1999). O 


\section{Erotismo dançante e as distâncias sociais entre homens e mulheres no Brasil}

surto revolucionário sexual dos anos 60 não atingiu todos os países da mesma maneira assim como todas as regiões de um mesmo país, a exemplo do Brasil. Isso pressiona-nos a olhar o desenvolvimento das tradições emocionais e os códigos dos costumes de um país a partir do curso próprio de suas redes humanas (WOUTERS, 2004).

A vigência da "regra" patriarcal em muitos segmentos da sociedade brasileira foi um obstáculo à abertura mais intensa de espaços "livres" para que homens e mulheres, jovens e adultos pudessem ter experiências de cortejo e sedução por eles mesmos, sem intermediários. Em parte, o sucesso da obediência à "regra" patriarcal se sustentava em uma balança de poder entre homens e mulheres, o equilíbrio que expressava a boa reputação de uma família dependia da concentração do poder econômico e educacional pelos homens adultos e dos poderes de cuidado psíquico, assistencial e doméstico pelas mulheres. Entretanto, é necessário contar nessa balança outras formas de concentração de poder tão ou mais importantes para a reprodução da "regra": o maior acesso às posições jurídicas e policiais pelos homens.

Em outra entrevista, tivemos uma oportunidade de ouvir um relato da vigência da regra patriarcal do ponto de vista de um homem. Vindo do interior de Alagoas para a capital, Maceió, relatou-me que aos 16 anos relacionou-se com uma menina, da mesma idade. "Avancei o sinal", explicou, referindo-se ao fato de ter tido relações sexuais. A mãe da menina dirigiu-se a ele, exigindo a formalização do casamento. De acordo com o senhor de 64 anos, referindo-se ao passado, "mesmo 'de menor', eu falei que ia assumir minhas responsabilidades, mas falei com ela, casar eu caso, mas não fico um dia com essa mulher; na saída, é cada um para um lado".

O detalhe importante é que a resolução dessa divergência, como outros conflitos de honra familiar, podia se dar em uma 
delegacia, algo não raro de acontecer entre os mais pobres, aspecto hoje em dia esquecido. Um homem ou, no caso, uma mulher, tinha legitimidade para invocar uma "regra" patriarcal junto a um delegado, visando "limpar" a honra familiar. Até o momento da entrevista, ele estava protocolarmente casado com a mulher com quem tinha tido tal intercurso sexual sem nunca ter convivido. Posteriormente, havia tido um relacionamento estável de 17 anos e três filhos. O casamento acordado na delegacia era um aspecto da distância entre a formação sentimental e os códigos normativos vigente na sociedade alagoana.

Tais exemplos de vigência da "regra" patriarcal após os anos 60 mostram como os padrões matrimoniais e de aproximação erótico-sexual entre homens e mulheres de diferentes regiões do Brasil se desenvolveram de maneiras heterogêneas. Uma parte delas com exíguas camadas simbólicas de expressão livre de linguagens eróticas amorosas-sexuais. Para o que interessa chamar a atenção aqui, assinalo como a vigência da "regra" patriarcal em muitas "periferias" de cidades brasileiras limitava as condições de encontro e experimentação "livre" entre homens e mulheres, adultos e jovens.

Tais limites, tanto de condições de sobrevivência - as favelas são sempre lugares de urgências -, quanto normativos há sempre agentes que pleiteiam a realização da justiça em conflitos de interesses locais -, exerciam fortes pressões para que espaços erótico-dançantes se mantivessem restritos. Uma parte importante das experiências sexuais se davam na família na vizinhança, sem estar embaladas por linguagens eróticodançantes diferenciadas em lugares fora da família e das redes de assistência do bairro, como bailes e discotecas, além da escola (REIS e OLIVEIRA-MONTEIRO, 2017), em grande medida símbolos da autonomia da "regra" patriarcal ou da rede familiar, mesmo que extensa. 


\section{Erotismo dançante e as distâncias sociais entre homens e mulheres no Brasil}

Aliás, destaca Moura (2005), o significado da família e de sua extensão entre grupos "populares" está muito associado ao mundo doméstico e às redes de assistência mutua que se formam para além da unidade doméstica. É através de tais redes que também se desenvolvem campos de atratividade erótico-sexual e as regulamentações de parentesco. A partir de experiências de pesquisa em Belém, Salvador e Maceió observamos que tais campos afetivos foram substancialmente redimensionados com a redução das diferenças no acesso à educação e ao trabalho fora de casa em favor das mulheres, mas também em relação à redução da distância entre as formações sentimentais e suas representações nos códigos normativos erótico-sexuais das redes humanas mais abrangentes.

É significativa a alteração da balança de acesso à educação nos diferentes níveis durante o século XX. Se no início do século $X X$ a estrutura de oportunidade pendia muitos desfavoravelmente para os homens, após o surto democratizador da educação após os anos 30 do século $\mathrm{XX}$, tal balança pendeu consistentemente para o lado das mulheres. Nos anos 60 elas já lideram as matrículas no ensino médio, e nos anos 80, já são maioria no acesso ao ensino superior (BELTRÃO e ALVES, 2004). Uma das expressões dessa redução parece apresentar-se na ampliação da liberdade com que parte das mulheres e homens jovens puderam ampliar repertórios de gestos dançantes que simulam atos de coito, sedução e de amor ainda que tenham enfrentado fortes julgamentos depreciativos. Os espaços dessa ampliação de linguagens e experiências mimético-eróticas foram justamente bares, churrasquinhos, bailes, discotecas, shows públicos, reforçados pela divulgação maciça de repertórios eróticos musicais-dançantes em TV's e através da internet, acessada em computadores, tablets e celulares.

Vale a pena notar as ambivalências geradas pela ampliação desses espaços, integrando mulheres mais jovens e 
mais velhas, homens mais velhos e mais jovens a partir de um registro de campo de um show de forró em uma cidade do interior de Alagoas:

Elas estão no show, dançam, se divertem, mas o comportamento de uma delas, uma mulher de meia-idade, não é igual ao das mulheres mais novas. Os seus passos de dança não são tão sensuais e eróticos, e o julgamento que algumas tem em relação às mais jovens expressam aproximação e alguma divergência.

Maria tem 50 anos e eu estava acompanhando-a junto com seu grupo de amigas, todas mulheres de meia idade. Em um determinado momento do show estávamos sentadas na lateral do clube, passa uma moça e um homem abraçados. Ela olha e diz: Essa menina já ficou com uns dois caras, quando eu fui no banheiro ela tava com um e agora tá com outro. Sei não!... O casal fica um pouco em nossa frente, ele por trás da parceira, agarrado em sua cintura, acariciando as nádegas da mesma. Maria observa tudo e fala ao meu ouvido: "Depois a mãe não sabe porque a filha tá perdida, olha a mão boba dele, e ela nem aí...Tá é gostando!"

Encontro Maria em outra festa. Eu estava junto com um amigo e a filha de Maria, que é minha amiga. Ela para na nossa frente, me dá um abraço e fica conversando sobre coisas triviais. Depois ela olha pra trás e diz: "estão vendo aquele velho alí? Aquele de verde? Pronto, ele tá me paquerando faz 


\title{
Erotismo dançante e as distâncias sociais entre homens e mulheres no Brasil
}

\begin{abstract}
tempo, mas quero não. A filha diz: não, mãe...queira mesmo não. Prefiro o meu pai, e começa a rir. Diga logo a ele que não quer. Maria responde: "não é assim, ele é primo de Gorete e eu já conheço de outros carnavais. Deixa ele me paquerar, não quero mesmo. Eu gosto é de novinhos. Vocês vão ver... Logo, logo terão uma surpresa." Começa a rir e diz que vai encontrar as amigas. (Registro de campo)
\end{abstract}

No trecho, diferentes direções afetivas em uma mesma pessoa que expressa concretamente o significado da redução das distâncias psíquico-sociais entre adultos e jovens, homens e mulheres. Uma mulher de meia-idade deprecia a liberdade com que outra mais jovem experimenta os "amassos" eróticosexuais e a apresentação de seu prazer. De outro, rejeita a paquera de um homem mais velho e torna público sua intenção de paquerar garotos mais jovens. O que integra as mulheres de diferentes gerações é o espaço que as aproxima assim como dos homens mais velhos e mais novos: um show de forró no qual a dança é uma das principais linguagens de expressão da aproximação "livre" entre pessoas com valências amorososexuais abertas.

Cinco décadas atrás tais aproximações seriam improváveis. Os espaços eram bem demarcados entre a diversão dos mais jovens e dos mais velhos, sendo bloqueados aos primeiros a noite e a diversão erótica-sexual. Aos mais jovens estava reservada a Igreja e a praça, até o sol se pôr, com olhares, trocas de mensagens e brincadeiras eróticas não sexuais, enquanto que aos mais velhos estava disponível um repertório restrito de lugares dançantes, bastante escondidos e pouco públicos pois "livre" era um qualificativo pouco prestigioso para uma mulher de cidades do interior e, em determinados contextos, também das capitais. A vida erótico- 
sexual de uma jovem poderia se iniciar sob fortes camadas de tabu dentro de casa, em relações com pessoas conhecidas a partir do mundo familiar e doméstico, ou, ainda, na vizinhança, algumas ou muitas vezes sob violência. Não expressavam-se em linguagens públicas. Basta lembrar, de acordo com Azevedo (1978), que namoro era uma palavra desprestigiosa nos anos 70 para representar a situação de uma garota solteira mas que começava um envolvimento amoroso com um rapaz. Tal situação tendia a ser mantida sob o manto do silêncio, das fofocas e do segredo até que, eventualmente, o casal viesse a assumir um noivado. $\mathrm{O}$ namoro não era legítimo para uma garota ter boa reputação, pois assinalava a transitoriedade de experiências de intimidade erótica-sexual.

Outra dimensão nas quais podemos apreciar a redução relativa das distâncias sociais entre homens e mulheres é a do consumo de bens e serviços. As reportagens que divulgam resultados de pesquisas de mercado são evidências bastante úteis a esse respeito. Uma vez tendo sido informadas as fontes, tomamos como informação confiável, especialmente porque muitas vezes não temos acesso às pesquisas pagas, vendidas prioritariamente para companhias. Em uma dessas reportagens, é informado que o instituto de pesquisa Datapopular constatou que entre 2002 e 2012, a renda das mulheres teria avançado $67 \%$, enquanto a dos homens, no mesmo período, teria aumentado $40 \%$. Informa, ainda, que os postos de trabalho entre as mulheres cresceram $75 \%$, enquanto que entre os homens o crescimento foi de 59\%, no mesmo período. Entretanto, mais expressivas do movimento que desejamos destacar, o do aumento de espaço para a gratificação própria em espaços de competições em apresentações públicas da aparência e de gestos erótico sexuais, são as informações sobre os seus gastos. Outra reportagem divulgou pesquisa feita pela Sophia Mind Pesquisa e Inteligência de Mercado, especializada no levantamento de informações sobre mulheres consumidoras, 


\section{Erotismo dançante e as distâncias sociais entre homens e mulheres no Brasil}

inferindo que no início de 2012 55\% das mulheres compravam ao menos uma peça de roupa por mês. Há ainda a informação de que também em 2012 foram responsáveis por movimentar 1,3 trilhão em bens e consumo, sendo consideradas pela reportagem como o maior mercado consumidor brasileiro daquele momento. $\mathrm{Na}$ mesma pesquisa apontava-se que $34 \%$ das mulheres até 25 anos tinham na moda o principal item de gasto. Entre as mulheres com idade entre 26 e 30 anos o gasto com diversão fora de casa se equiparava ao gasto com moda. Há, ainda, o sucesso recente do livro 50 tons de cinza, que vendeu 100.000 exemplares em apenas 16 dias no Brasil, tendo se tornado um best-seller mundial, no que tem sido alardeado como um tipo de literatura anteriormente inexistente, focada em um tipo de prazer prioritariamente sexual, menos romantizado, direcionado para mulheres. Nesses tipos de mercados, a raridade do bem é altamente dependente do valor que as mulheres entre si simbolizam, vinculadas a redes com códigos sociais de convívio relativamente apartados dos vigentes entre formas de convívio mais exclusivas dos homens entre si. A percepção vagamente disseminada de que as mulheres se vestem para mulheres é, a esse respeito, significativa. Outro exemplo comum é o fato de muitas mulheres, quando possuem independência em relação aos "seus" homens-parceiros dependentes financeiramente delas, fornecerem os carros os quais são proprietárias para que seus namorados e esposos dirijam, a luz de todos, sem qualquer tipo de envergonhamento, convertendo uma posição econômica em uma posição prestigiosa no mercado de avaliações do bem-estar amoroso entre as próprias mulheres, a de ser dependente afetiva, e de ter essa dependência completada por outro, aos olhos públicos. O contrário é inteiramente incomum. Aliás, a necessidade de publicidade do valor próprio para o mercado do amor-sexual é, nesse sentido, uma força constrangedora mais explícita entre as mulheres como linguagem de competição 
entre elas. Os valores de ser provedora, e parecer provedora, ainda ficam em segundo plano quando uma parte das mulheres leva em conta o que vale mais para as suas estimas como "mulher" em muitas regiões do Brasil.

Assim, compreender o significado da expansão de um repertório de gestos eróticos-sexuais através de danças e músicas parece importante porque ele nos dá acesso a transformação das formas de controles sociais entre homens e mulheres, jovens e adultos, classes médias e pobres através das formas como as estruturas psíquicas expressam seus autocontroles. Afinal, ao que nos referimos quando falamos de gestos erótico-dançantes?

Erótico-dançante: repertório de simulações, prazeres e frustrações em festas musicais-dançantes

Experiências de pesquisa em diferentes cidades brasileiras permitiu observações em "bailes" organizados como um tipo de empreendimento de diversão, em bairros populares, com distintas direções e graus de profissionalização (RODRIGUES, 2011). Um dos aspectos que destacava-se nessas situações era o momento em que grande parcela dos indivíduos orientava-se para o ambiente sonoro elaborado por agentes contratados, tais como DJ's e Bandas. Nessas ocasiões, boa parte dos indivíduos-clientes é afetada por expressões musicais previamente aprendidas, desencadeando aumentos de intensidade da vibração das suas emoções, ao serem reconhecidos os padrões de sons. Ativados pelo aquário sonoro, canalizam as pulsações emocionais para disposições dançantes - individuais, em pares, ou em grupos - nas quais se podem observar atos simulatórios de gestos de sedução sexual ou de sexo propriamente dito, sem que suas apresentações culminassem na efetivação de atos erótico-sexuais, representados simbolicamente por estas expressões. 


\section{Erotismo dançante e as distâncias sociais entre homens e mulheres no Brasil}

Uma parte dos julgamentos desfavoráveis sobre estas músicas está justamente referida ao baixo valor conferido às letras, danças e coreografias, associadas a elas que, de alguma forma, estimulam os indivíduos a exercerem as dimensões expressivas dos corpos na direção de representar publicamente gestos, diante de estranhos ou quase estranhos, com um reduzido grau de vergonha, que simulam diversos estilos de coito, e, em alguns casos, gestos semelhantes aos de oferecimento sexual fácil, saber-fazer anteriormente "associado a" e "concentrado por" prostitutas e dançarinas, profissionais da excitação sexual ${ }^{3}$, ou mulheres avaliadas como de baixo valor para o mercado de casamentos, ainda que, via de regra, não se observe nessas situações a efetivação de coitos ou a atuação pública de mulheres como profissionais do sexo ${ }^{4}$. Entretanto, os homens e mulheres clientes podem extrair prazer autêntico e efetivo da simples experiência dessas simulações e representações miméticas. Ademais, essas também podem servir de linguagens através das quais se pode acessar um intercurso de carícias sexuais efetivas, como roçar o sexo nas

3 Para termos uma ideia do tipo de liberdade expressiva desses agentes vale observar os filmes L'apolinide (2011) e "Depois da Chuva" (1999). Nesses filmes, destaco as performances gestuais e os dilemas existenciais das prostitutas, relacionadas às suas posições como pessoas que tinham boa parte de seu valor humano definido por posições tabu, como pessoas que cumpriam funções de satisfação sexual para outros, podendo vivenciar mais livremente nesses espaços os desejos amoro-sexuais próprios, mas que, rotineiramente, precisavam lidar com a frustração constante de terem os seus desejos amorosos frustrados estigmatizados.

${ }^{4}$ A não ser em situações em que os bailes são publicamente reconhecidos como ponto de encontro entre clientes à procura de prazer sexual efetivo e as mulheres profissionais na oferta de seus corpos mas que, ainda assim, o baile serve de ponto de encontro e negociação, mas nunca da efetivação do coito. 
pernas do par, mas, na maioria dos intercursos dançantes, as simples afecções decorrentes da expressão dos gestos esgotam a dinâmica de geração e finalização do prazer.

Em suma, essas representações miméticas - geralmente associadas a representações discursivas, ambas associadas a padrões rítmico-sonoros feitos para dançar - são linguagens humanas que funcionam como fios simbólico-afetivos que ligam pessoas em configurações-baile. As vibrações desses "cordões emocionais-expressivos" entre pessoas mutuamente dependentes em uma festa podem ser reconhecidas como agradáveis e prazerosos tecidos que ondulam pulsões divertidas, mas, igualmente, podem significar contínuas frustrações decorrentes de não correspondências afetivas geradas nos mínimos investimentos gestuais, como olhares e uma floresta de movimentos corporais, especialmente os da face. O tempo dessas dinâmicas é contado em segundos e minutos, mas são sucessivas e incessantes quando um baile ou festa é divertido. Nessas circunstâncias, os indivíduos são submetidos a uma elevada pressão de excitação e, como outra face da mesma moeda, submetidos a uma pressão para segurar os impulsos que os conduziriam a um aumento da intimidade corporal com estranhos (as), à desinibição completa para a autossatisfação mediante outros, situação na qual se deixariam levar pelos desejos ascendentes e vibrantes ultrapassando as barreiras psíquicas que outros, em forças contrárias, impõem. Forças como a de uma mulher refutar um cortejo dançante, a de um homem não dar atenção a uma mulher que se sugere para ele, ou tensões mais sutis como a de uma mulher estabelecer limites de exploração erótica para seu par durante a dança ou a de um homem desempenhar protocolarmente uma dança quando seu par feminino desejaria mais ousadia e mais apalpamento sobre seu corpo.

Tais situações levam a um "suportamento" de um elevado grau de tensão-excitação nos corpos dos 


\section{Erotismo dançante e as distâncias sociais entre homens e mulheres no Brasil}

frequentadores (ELIAS, 1992) das emoções eróticas. Estas podem ser estabilizadas no decurso dos movimentos miméticodançantes, eivados do reconhecimento tácito encarnado nos corpos, expressando uma regra agonística, até certo ponto maleável, de que a intimidade alcançada no momento da dança é parte de um jogo de prazeres motores envoltos em sentimentos e emoções, ainda que as simulações e antecipações imaginativas gerem efetivamente emoções; não na direção da concretização do coito ou da efetiva vivência de um relacionamento íntimo entre amantes, mas no prazer da imitação de movimentos que simbolizam amor ou sexo. Hanna - uma respeitada etnógrafa e estudiosa de diferentes danças fornece, a este respeito, uma visão bastante clara:

Mais do que uma precursora da intimidade sexual, a dança pode ser sublimação sexual de caráter físico e psicológico. A satisfação orgástica pode vir do real ou empático envolvimento da dança. A dança frequentemente tem a excitação, a liberação e a exaustação características do clímax sexual (HANNA, 1999, p. 84)

Para aumentar a clareza do tipo de fenômeno que estamos a destacar, forneço uma síntese de descrições de observações de bailes conduzidos por DJ's de reggae, em diferentes ocasiões em Maceió, capital do estado de Alagoas, focando especialmente o desenvolvimento da festa e a caracterização dos momentos-ápice de um padrão coletivo de excitação tensionado pelo ambiente sonoro elaborado pelo DJ, além do cortejo para a dança e a própria dança como momento de geração e finalização de prazeres miméticos eróticodançantes:

As primeiras pessoas que chegavam ao baile encontravam o centro do espaço de dança 
Fernando de Jesus Rodrigues e Letícia Souza

vazio, apenas o DJ auxiliar tocava as músicas, uma oportunidade de mostrar talento para divertir o público, "preparando o terreno" para a performance do DJ principal que chegaria depois da meia-noite. Homens e mulheres, incluindo adolescentes de ambos os sexos (chamou-me a atenção o número expressivo de mulheres) iam tomando posição, encostando-se nas paredes. A agitação era parcial e rarefeita. Indivíduos, especialmente mulheres, movimentavam-se sozinhas ou dançando em duplas, acompanhando as músicas. Os homens tendiam a ficar na posição de observadores, em pequenas hordas, algumas delas em torno do consumo discreto de entorpecentes. Na parte inicial do baile, as danças de pares eram mais raras. As pessoas se concentravam alinhadas ao longo das duas paredes, ficando o centro relativamente vazio. Havia poucos cruzamentos de pessoas de um lado para outro. As pessoas que dançavam individualmente ainda estavam pouco excitadas. Eram rarefeitos os cortejamentos para dançar. As pessoas estavam relativamente mais voltadas para si mesmas ou para os companheiros de festas com quem vieram do que para o ambiente sonoro elaborado pelo DJ e para o intercurso com estranhos. À medida que mais pessoas chegavam ao baile, que iam se embriagando e se entorpecendo, e a sequência de músicas ia sendo administrada pelo condutor musical, ministrando ao público sucessos reconhecidos pelo público no estilo "reggae raiz" e 'melô', alterava-se a estrutura de 


\title{
Erotismo dançante e as distâncias sociais entre homens e mulheres no Brasil
}

\begin{abstract}
disposições emocionais em uma direção específica: as pessoas iam sendo mais afetadas pela ambiência sonora e, simultaneamente, aumentavam suas aberturas afetivas umas para outras, seja através de danças de par, seja através de danças soltas, ambas com gestos que representavam performances eróticosexuais, com um grau menor de inibição, tornando-se os focos principais de atração dos frequentadores que observavam a festa. $\mathrm{Na}$ mesma medida, aumentavam-se as aberturas afetivas dos frequentadoresclientes para o próprio DJ, criando-se um tipo de vínculo que lhe pressionava o desempenho da função de animador, interagindo verbalmente com o público, além da função de elaborador da paisagem sonora. A um determinado estágio de desenvolvimento das mútuas interações dos frequentadores entre si e entre estes e o DJ principal, alcançava-se um padrão de excitações elevado relativamente estável, ora aumentando ora reduzindo a intensidade, mas mantendo-se intenso o suficiente para que o DJ criasse as condições de reiteração de diversos momentos de êxtase eróticodançante, durante uma, duas, ou três horas, quando, em um movimento inverso, as pessoas cansavam-se, se desinteressavam ou iam efetivar as relações erótico-sexuais em outro espaço, desestruturando a rede de ligações que criava o padrão coletivo de êxtase e de seus controles existente. (Registro de campo)
\end{abstract}


Trata-se de uma síntese da estrutura de desenvolvimento da festa, indicando que o momento-ápice de intensificação das emoções ocorre nos momentos de êxtase erótico-dançante. Essa estrutura de desenvolvimento pode servir utilmente para compreender outras configurações-baile específicas. Mas em que consiste a dinâmica psíquico-motora dessas emoções denominadas erótico-dançantes? As descrições a seguir se referem às dinâmicas observadas no mesmo tipo de baile. Com elas, se pretende fornecer uma imagem do movimento da dinâmica de gratificação psíquico-social vinculada à adoção de uma linguagem dançante, atendendo o pólo egóico das pessoas, realizado relacionalmente em um baile:

Uma sequência de gestos chamou-me a atenção em algumas das mulheres do baile voltadas para o palco que dançavam sozinhas. Poderia descrevê-la da seguinte forma: tendo por base o movimento dançante de quadril, levado em parte pelos movimentos que flexionavam alternadamente os joelhos, desenvolvia-se um movimento sensual dos quadris, um rebolado. De modo complementar e coordenado, percorria o seu quadril com movimento de mãos, acompanhando o formato do seu corpo até a região do busto para, em seguida, fazer movimentos circulatórios com as mãos, especialmente com as pontas dos dedos, simulando um auto estímulo erótico nos seios, mas sem tocá-los. Uma vez concluído essa série gestual, a mulher pode repetir a sequência como um desenvolvimento de um estado de excitação anteriormente alcançado, renovando a busca por satisfação própria 


\section{Erotismo dançante e as distâncias sociais entre homens e mulheres no Brasil}

previamente vivenciada. Um dos índices de expressão da satisfação dessa série de movimentos dançantes direcionadas para o auto estímulo erótico ganha forma na feição do rosto, fechando os olhos, algumas vezes colocando levemente a língua para fora, algumas vezes buscando no "canto do olho" um olhar de alguém para ela. $\mathrm{O}$ desenvolvimento mimético-motor decalcava-se na face na medida em que a série gestual implicada na relação entre o 'movimento rebolado' e a 'performance das mãos sobre o corpo' ganhava um automatismo próprio e adquiria uma certa duração. Em outros termos, adquiria um grau de descontração excitada, e um padrão de intensificação tensamente equilibrada de êxtase. Durante essa cadeia de movimentos, o rosto e os olhos gradativamente desligavam-se de possíveis impactos da visão própria do frequentador de seu entorno, voltando-se para o aumento da sensibilidade com seu próprio êxtase gerado pela interação a ambiência sonora e a imaginação motora. Em algumas mulheres, esse estado pôde ser observado nos momentos em que os olhos fechavam, geralmente acompanhados de um movimento de abaixar tenuemente a cabeça para em seguida elevá-la, com a mesma cadência. Difícil não pensar que o ritmo dos movimentos não estivesse ligado a alguma forma de dinâmica psíquica imaginativa. Todo esse movimento dava-se de modo coordenado com os movimentos padronizados de pernas, quadril e mãos. Nesses momentos, pude observar que 
Fernando de Jesus Rodrigues e Letícia Souza

\begin{abstract}
dificilmente poderia enxergar algo ou prestar atenção em qualquer movimento que as pudessem retirar de seus estados de excitação, embora na maioria das vezes esse estado não durasse mais que algumas dezenas de segundos ou minutos. Poderia tomar esse estado, encontrado apenas em determinadas pessoas que dançavam sozinhas em momentos específicos do baile, como referência empírico-vivencial de definição do gradiente elevado de ensimesmamento emocional e de satisfação própria com a mimese-motora que simulava gestos de auto estímulo erótico da interação com o ambiente sonoro e o prazer de outras pessoas por verem-na desinibida. Com isso, se quer dizer que o prazer advinha de uma padronização de gestos que, de alguma forma, representava formas efetivas de representações auto-eróticas sexuais, e o prazer era extraído dessa representação, não da estimulação direta dos órgãos sexuais, mas situada na dimensão simbólicoexpressiva da imaginação motora ativada na corporeidade. (Registro de campo)
\end{abstract}

Os momentos de êxtase erótico-dançante também eram compostos pelas mutuas ligações afetivas entre estranhos ou quase estranhos, expressas nos múltiplos casais que, por alguns minutos, extraíam o prazer da elevada excitação erótica dançante, vivenciada no compartilhamento de intimidades através da dança reggae como dança de par:

Um aspecto que chamou a atenção inicialmente no processo que leva a dança de par é o cortejo da jovem pelo moço. Nas diferentes oportunidades que tive de 


\section{Erotismo dançante e as distâncias sociais entre homens e mulheres no Brasil}

observar esse momento identifiquei a ausência de qualquer etiqueta verbal. O gesto de ir em direção à moça e o leve estender de mãos, de modo rápido, ressaltese, não lento ou cadenciado, era o primeiro movimento reconhecido pela mulher para que fizesse uma escolha e ativasse as suas disposições para a dança. Até o momento, tenho tomado a ausência de qualquer cortejamento verbal, aliado ao baixo índice de rejeição das mulheres para a dança, como um índice de sedimentação do conhecimento das regras de controle das emoções entre homens e mulheres no horizonte de expectativas do que será o momento do prazer dançante. Se considerarmos, ademais, que as observações feitas indicam igualmente um baixo índice de intercurso de intimidades eróticas efetivas pelos pares durante a dança, podemos pensar que a barreira social erguida como controle dos desejos de ir além da simulação erótico-dançante, tanto por parte de homens quanto de mulheres, é bastante significativa na sociedade abrangente. Vamos à descrição da dança nos casos em que o cortejo ter sido bem sucedido.

Um dos primeiros movimentos mútuos é o abraço íntimo. A mulher coloca os dois cotovelos sobre cada um dos ombros de seu par e, com as mãos, segura ou simula segurar a parte de trás da cabeça do parceiro, puxando-a até que ela fique lado a lado de seu rosto em um tipo de gesto que, em períodos anteriores, seria aceitável apenas entre casais íntimos. $\mathrm{O}$ curso da 
Fernando de Jesus Rodrigues e Letícia Souza

dança desenvolve-se da seguinte maneira: a mulher, abraçada ao pescoço do parceiro, fica com tronco, quadril e pernas livres para realizar caminhados ou pequenos passos em círculos, acompanhados de rebolado, acentuando o movimento alternado da cintura e, acompanhando, das nádegas, de um lado para outro, no tempo e no ritmo que ela lidera. A mulher efetivamente conduz o par. Os movimentos do homem são simples. Limita-se a acompanhar o andar rebolado que a mulher conduz. No momento clímax do erotismo dançante, o homem, simulando séries de apalpamentos, percorre com as duas mãos o corpo da parceira, do ombro até as nádegas, avançando ainda para as pernas da mulher. Em boa parte das vezes essa série gestual dá-se sem tocar o corpo, mas, eventualmente, de maneira ousada, tocando e roçando a mão no bumbum da parceira, numa luta tensa de conquistas e frustrações, desejar e ser desejada, de acordo com avaliações tácitas, para alcançar outro estágio de intercurso erótico. A determinada altura da dança, o casal se fixa em um ponto e chega-se ao momento em que a tensão das emoções eróticas alcança o seu nível mais elevado. A mulher posiciona suas pernas de forma que o joelho do parceiro fique entre elas. O homem projeta o joelho à frente; a mulher projeta o tronco e, junto com ele, empina o bumbum para trás, em gestos ousados que lembram dançarinas profissionais da sedução sexual de períodos anteriores. $\mathrm{O}$ tronco do homem fica ligeiramente arqueado, ficando algumas 


\section{Erotismo dançante e as distâncias sociais entre homens e mulheres no Brasil}

vezes levemente agachado, para poder acompanhar o movimento da mulher de rebolar em cima de seu joelho no momento de máxima excitação. Em um movimento altamente sensual, a mulher mexe a cintura com grande destreza, em círculos, durante um sentido (horário ou anti-horário) para, a certa altura, fazer o movimento no sentido oposto. A sequência desse gesto é realizada em cima do joelho do parceiro, simulando uma sedução erótica-sexual. As mais habilidosas estereotipam o rebolado e cadenciam o movimento circular da cintura e suas quebras de sentido repentinas em diferentes tempos, lembrando alguns movimentos de cintura da dança do ventre e em concordância com a "dança pulada" do reggae como dança solta. Muitos homens ficam observando a mulher expor sua sensualidade para ele, enquanto ele simula os atos de passar a mão por seu corpo, apalpando-a. Quem não conhece de perto a lógica do intercurso dançante do baile poderia facilmente pensar que se trata de namorados muito íntimos, ou simplesmente que teriam tido um intercurso de carícias amoroso-sexuais temporárias, reconhecido na prática do "ficar". Mas eis que a música termina e imediatamente toda a tensão erótica é desestruturada e cada indivíduo do par corre para um lado do baile, como se nunca tivessem se conhecido. Eis o principal índice do elevado "suportamento" da tensão erótica que vincula duas pessoas estranhas, permitindo e limitando a gestualidade e emoção erótica, diversas vezes, sem que redunde em um intercurso sexual ou 
Os trechos sintetizam fenômenos que podem ser compreendidos como eventos estruturados por um padrão de gratificação psíquica diversional, gerada por um curso de interações entre pessoas através de linguagens miméticas erótico-dançantes. A descrição detalhada de gestos dançantes expressivos de fenômenos de recompensas afetivas temporárias e decorrentes da representação motora de gestos sexuais - visa realçar que a impulsão das pessoas para mobilizarem símbolos potencialmente armazenados em seus corpos, com os quais dão formas às simulações que geram tensões-excitações, podem ser compreendidas como cursos próprios de alimentação e cessação de prazeres relativos às funções de envolvimento egóico com as emoções de autossatisfação e que, como funções psíquicas, estão atreladas às outras funções sócio-afetivas que ligam os indivíduos uns aos outros.

Apesar de esses cursos estruturados de gratificação de curta duração estarem direcionados, através de símbolos sonoro-motores, para o desempenho de funções psíquicas com elevado grau de orientação para o pólo "eu”, elas não são formadas pelo pólo "eu" isoladamente. O "eu", para lembrarmos descobertas em sociologia e psicologia, é uma função da relação da pessoa consigo mesma, modelada através de outros (ELIAS, 1994; WINNICOTT, 1990). Como tal, um resultado da diferenciação de funções psíquicas maturadas em diferenciadas jornadas de experimentação de "dependência" e "independência" com outros.

Podemos, assim, nos aproximar com mais familiaridade da ideia de que as linguagens de satisfação de "si mesmo" são modeladas socialmente, e formam figuras através das quais se reconhece um tipo de prazer egocentrado. Compreendê-las, ajuda a compreender o estágio de desenvolvimento de 


\section{Erotismo dançante e as distâncias sociais entre homens e mulheres no Brasil}

sociedades nas quais, comparativamente com o passado, houve tanto um aumento da quantidade quanto uma diversificação dos repertórios de símbolos orientados para as satisfações do pólo "eu", sem capas denegadoras do prazer egóico, mas sob novas formas de regulamentações da expressão social das emoções (WOUTERS, 2007; ELIAS, 2001).

Estreitamente relacionado a esse processo, há o crescimento e a diversificação de diversões com linguagens de simulação erótico-sexual. A necessidade de denegação do prazer próprio que se manifesta inúmeras vezes na vida de uma pessoa e nas formas de reprodução social é uma forte expressão da dependência entre a forma do prazer egóico e imagens sociais com funções normativas. Na esteira dessa percepção, podemos apontar que as formas de satisfação de si são tanto forças constrangedoras quanto constrangidas pelas maneiras como as pessoas entre si se tornam dependentes e, simultaneamente, constituem símbolos de gratificação egocentrados - exibidos publicamente -, ou forçadas a inibirem a auto expressão pública de prazer próprio, ambas as direções amarradas por vínculos sociais que forçam uma orientação alter-centrada.

As dinâmicas de gratificação psíquicas egóicas são vistas, ainda, em muitas regiões do acervo de conhecimento comum ou especializado, como dinâmicas patológicas em si mesmas, e não como parte de uma balança de tensões psíquicas, socialmente formada e estruturada.

Se considerarmos, em relação ao passado, a expansão de polos de gravitação de pessoas em torno de bares, boates, bailes, em seus diversos formatos, públicos, privados, negócios de baixo custo em periferias urbanas, casas prestigiadas de atração de pessoas de distintas classificações sociais em zonas bem reputadas, até mega eventos de elevada organização profissional, em escala nacional e transnacional além, ainda, da presença íntima de imagens e sons musical-dançantes chegados 
do rádio, da televisão, da internet e de celulares veremos que a estrutura de apresentação das emoções alterou-se, permitindo maior liberdade de expressão erótica, amorosa e sexual, particularmente das mulheres, através de gestos-motores, aumentando o repertório de linguagem de excitação amorosa sexual disponível em relação ao antigo acervo de linguagens eróticas, eminentente literárias e altamente dissimuladas das classes médias e altas do Brasil. Podemos observar que as disposições para representações de gestos erótico-dançantes para estranhos, numa direção mimético-sexual, como uma expressão de homens e mulheres comuns que buscam oportunidades de vivências de prazeres diversionais, estão disseminadas em diversas instituições que propiciaram o aumento das dimensões expressivas postas em interdependências entre homens e mulheres durante o século XX no Brasil.

\section{Concluindo: diversificar o vocabulário sobre desigualdade e balança de poder entre homens e mulheres, adultos e jovens}

Mostra-se importante diferenciar o vocabulário utilizado para avaliar o equilíbrio de poder entre homens e mulheres, adultos e jovens, em relação ao acervo de conhecimento existente. Uma parte majoritária do saber disponível sobre avaliação da igualdade/desigualdade entre homens e mulheres está norteada pelos problemas de acesso a renda, a posições no mercado de trabalho, ao acesso à educação e a posições de representação política. As imagens dessas funções sociais fazem parte acervo de símbolos que tomamos como auto evidentes para compreender tanto a condição atual de nossa sociedade quanto os caminhos para os quais acreditamos que, enquanto sociedade, devamos rumar.

Como efeito da condição geral de o investigador estar altamente submetido às pressões afetivas decorrentes do cultivo 


\section{Erotismo dançante e as distâncias sociais entre homens e mulheres no Brasil}

de ideais dos grupos nos quais está inserido, tende-se a cristalizar avaliações de dimensões parciais da vida como se pudessem abarcar a compreensão de todas as outras. Resultado: a compreensão das diferentes forças, em um modelo integrado, fica grandemente prejudicada.

A forte idealização de tradições simbólicas de poder econômica e política, ligadas aos processos de industrialização e profissionalização das sociedades europeias e brasileira durante o século $X X$, dificulta enxergar outras dimensões de avaliação da dignidade humana e, nesse sentido, da importância de outros ideais na composição do conjunto de pressões que fazem desdobrar as dependências humanas. Parcialmente, estes bloqueios provêm da dimensão das lutas humanas decorrentes da divisão de lógicas de transmissão de símbolos estruturadas em termos de homens e mulheres como pertencentes a redes sociais distintas. Uma dessas dimensões expressivas especificamente femininas, que saíram da zona reclusa da dominação doméstico-familiar, escolar e religiosa ou de espaços tabu, tais como prostíbulos e bairros populares foi à exposição das emoções em termos de imitações explícitas de gestos erótico-sexuais.

Um dos aspectos que facilmente passa despercebido é que a diversificação dos espaços de exposição das emoções erótico-sexuais, presentes em estruturas de comunicação e informação de elevado poder de integração de distintos estratos sociais, contemporaneamente, está relacionada com uma batalha simbólica, de longa duração, na qual o ponto central da disputa é o valor da mulher como foco do desejo erótico de outros. Em outros termos, que um dos pontos importantes o qual parcelas importantes das mulheres (mas também dos homens) extraem motivação para viver e lutar, formando uma avaliação de seu valor próprio, portanto, simbolização que faz parte das forças efetivas da configuração social global, são as linguagens através das quais as mulheres esforçam-se para 
esculpirem suas aparências e, dessa forma, batalham para tornarem-se referências gravitacionais da atenção de outros pelo valor que possuem como apresentadoras de expressões erótico-sexuais. Mais ainda, que essas disputas não se dão apenas como se homens e mulheres se colocassem de maneiras absolutamente opostas uns contra os outros. Boa parte dessas disputas está relacionada com o cultivo das "artes" de exposição erótica em competições estruturadas pelas mulheres entre si, como um campo de lutas relativamente próprio em relação a dimensões marcadas por batalhas que travam contra os homens. Uma parte do problema está relacionada com o fato de os conflitos entre as mulheres estarem atualmente mais fracamente sujeitos às lógicas de controle e disciplinamento oriundas de esferas da vida nas quais vige a crença de que a liberdade erótica das mulheres desestabiliza a ordem social.

Ao aumentarem o acesso a recursos de poder em outros tipos de funções sociais, as mulheres fizeram crescer os constrangimentos sobre diversas dimensões da vida em que se relacionam com os homens, pressionando-os a se orientarem por critérios de avaliação de gestos erótico-sexuais em "espaços públicos", mais explícitos e com graus menores de sentimentos de vergonha, através dos quais se sentem reforçadas em suas estimas. Essa percepção existe, mas bastante difusa, em brincadeiras jocosas geralmente expostas em conversas dos homens entre si e das mulheres entre si.

Uma das transformações mais significativas a esse respeito se refere ao fato de que o fortalecimento maciço das mulheres em regiões da vida social, como nas relações de trabalho, no acesso à educação, no acesso à renda, através de benefícios estatais de proteção social, e no acesso a posições político-parlamentares, foram e têm sido convertido em investimentos na conquista de posições no mercado de casamentos e das aparências estético-eróticas. 


\section{Erotismo dançante e as distâncias sociais entre homens e mulheres no Brasil}

Em síntese, as tradições de lutas entre as próprias mulheres, pela boa reputação de suas imagens e gestos como referências de valor erótico-sexual e amoroso tem ultrapassado os bloqueios psíquico-sociais de estruturas de dominação anteriores. Tem se imposto como linguagens de dominação com maior grau de publicidade, que demandam maior conhecimento por parte dos homens, pelo papel que as lutas entre as próprias mulheres exercem nas redes nas quais eles passam a desempenhar papeis diversos, sofisticando-se e diferenciando-se, constrangendo funções sociais altamente prestigiosas para os homens como as funções profissionais ou as de pregação religiosa, pela apresentação discursiva, que em diversas confissões ascendentes contemporâneas, tem sido deslocada ou dividida com as cada vez mais importantes "pregações musical-dançantes" 5 .

Nesse sentido, pode soar mais razoável a ideia de que a aquisição de poder econômico ou político, por si mesma, não explica algumas das tendências sociais que resultaram nos equilíbrios de poder contemporâneos entre homens e mulheres no Brasil. Podemos pensar, com adequação, que a aquisição de

5 A percepção para as tensões entre linguagens diversionais e narrativas salvíficas e recompensadoras no seio de confissões religiosas é tributária de informações de orientandas de graduação (PAIVA, 2016; BARROS, 2017). Especialmente, destacam a alteração em determinadas facções religiosas neopentecostais, da predominância de funções expressivas discursivas para a prevalência de símbolos musical-dançantes, ficando relegado ao segundo plano as pregações dos pastores. Atualmente, uma parte dos conflitos acerca das normas sobre os rituais em Igrejas neopentecostais gravita em torno da importância da dança e do êxtase musical-dançante na organização dos cultos. Tenho a suspeita de que a importância assumida por expressões musicais e dançantes está relacionada a crescente relevância das mulheres como deslocamentos de poder no interior dos grupos sacerdotais. 
maiores recursos nessas mencionadas regiões da vida permitiu o aumento do gradiente de poder entre mulheres de diferentes estratos sociais em campos de lutas especificamente femininos, como batalhas mais livres por homens no mercado de casamentos ou por se sentirem bem avaliadas em suas reputações gestuais, desde a graciosidade até a sedução eróticosexual, entre as próprias mulheres, borrando as fronteiras de classes entre elas, desdobrando-se, parcialmente, em fronteiras de ideais estéticos erótico-sexuais.

O mundo do divertimento musical-dançante como os bailes, foi dos que conheceram maior expansão na segunda metade do século XX, decorrente da maior liberdade adquirida pela "mulher comum" para livremente concorrer por parceiros através da exibição explícita, com reduzido sentimento de vergonha, de expressões erótico-sexuais. Concursos de misses, programas de televisão e revistas de diferentes matizes, abertas à exposição do nu feminino, incluindo o segmento pornográfico, parecem ser expressões do mesmo conjunto de pressões. Houve, igualmente, uma democratização de bens e habilidades entre mulheres de distintos estratos sociais, o que permitiu a largos segmentos alcançarem alguns ideais de beleza, anteriormente expressos concentradamente entre as classes médias e altas. Ademais, na medida em que a competição se acirrou na direção de lutas cada vez mais explícitas para se tornar atração erótica em mercados amorosos e sexuais mais livres de constrangimentos econômicos, familiares, mesmo religiosos, aumentou-se a criação de novas variações expressivas estético-sexuais, mais ousadas, nítidas e diversas.

\section{Referências bibliográficas:}

ALVES, Elder P. Maia. A sociologia de um gênero: o baião. Maceió: Edufal, 2012. 
Erotismo dançante e as distâncias sociais entre homens e mulheres no Brasil

AZEVEDO, Thales de. "Fazer a corte no Brasil: o namoro e a paquera" In: Cahiers du monde hispaine et luso-brésilien, $\mathrm{n}^{\mathrm{o}}$ 30, Numéro consacré au Brésil, pp. 117-126, 1978.

BALIEIRO, Fernando de Figueiredo. Carmen Miranda e a performatividade da baiana. Contemporânea, v. 5, n. 1, p. 207234, 2015.

BELTRÃO, Kaizô Iwakami; ALVES, José Eustáquio Diniz. A reversão do hiato de gênero na educação brasileira no século XX. Anais da ABEP, p. 1-24, 2016. Disponível em: http://www.abep.org.br/publicacoes/index.php/anais/article/vie wFile/1421/1386, acessado em 05/04/2017.

CORRÊA, Mariza. Sobre a invenção da mulata. Cadernos Pagu, (6-7), pp.35-50, $1996 . \quad$ Disponível em: http://repositorio.unicamp.br/bitstream/REPOSIP/119823/1/ppe c 1860-2481-1-SM.pdf , acessado em 15/04/2017.

COSTA, Antônio Maurício Dias da. Festa na cidade: o circuito bregueiro de Belém do Pará. Belém: EDUEPA, 2009.

DEL PRIORE, Mary. História do amor no Brasil. São Paulo: Contexto, 2013.

DÓRIA, Rosa Marina Soares. Evolução do padrão de consumo das famílias brasileiras no período 2003-2009 e relações com a distribuição de renda. Dissertação de mestrado. Programa de Pós-graduação em Economia da Universidade Federal do Rio de Janeiro, 2007.

DUARTE, Cristina Maria Rabelais et al. Reflexos das políticas de saúde sobre as tendências da mortalidade infantil no Brasil: revisão da literatura sobre a última década. Caderno de Saúde Pública, Rio de Janeiro, 23(7):1511-1528, jul, 2007

EFEGE, Jota. Maxixe: a dança excomungada. Rio de Janeiro: Funarte, 2009.

ELIAS, Norbert. A sociedade dos indivíduos. Rio de Janeiro: Jorge Zahar Editor, 1994.

Bertand Brasil, 1998.

Envolvimento e alienação. Rio de Janeiro: 
A solidão dos moribundos seguido de "Envelhecer e morrer". Rio de Janeiro: Jorge Zahar Editor, 2001.

Escritos \& ensaios, vol. 1. Rio de Janeiro: Jorge Zahar Editor, 2006.

Introdução à Sociologia. Lisboa: Edições 70,

2011.

ESSINGER, Silvio. Batidão: uma história do funk. Record: Rio de Janeiro, 2005.

ESTATÍSTICAS brasileiras do século XX. Rio de Janeiro: IBGE, 2006

FONSECA, Claudia. Concepções de família e práticas de intervenção: uma contribuição antropológica. Saúde e Sociedade v.14, n.2, p.50-59, maio-ago 2005.

GIFFONI, Maria Amália Corrêa. Danças Folclóricas Brasileiras. São Paulo: Empresa Gráfica Editora Guia Fiscal, 1955.

GILLIAM, Angela. The Brazilian mulata: images in the global economy. Race \& class, v. 40, n. 1, p. 57-69, 1998.

GILLIAM, Angela; GILLIAM, Onik'a. Negociando a subjetividade de mulata no Brasil. Estudos Feministas, v. 3, n. 2, p. 525-543, 1995.

HANNA, Judith Lynne. Dança, sexo e gênero. Rio de Janeiro: Roxo, 1999.

HANCIAU, Nubia Tourrucôo Jacques. A representação da mulata na literatura brasileira: estereótipo e preconceito. 2002. Disponível

em:

http://www.repositorio.furg.br/bitstream/handle/1/2315/08 A\% 20representa\%C3\%A7\%C3\%A3o\%20da\%20mulata\%20na\%20lit eratura.pdf?sequence $=1$, acessado em 15/04/2017.

HERSCHMANN, Michael (org.). Abalando os anos 90: funk e hip-hop, globalização, violência e estilo cultural. Rio de Janeiro: Rocco, 1997. 
Erotismo dançante e as distâncias sociais entre homens e mulheres no Brasil

HERSCHMANN, Michael. O Funk e o Hip-Hop invadem a cena. Rio de Janeiro: Editora UFRJ, 2000.

HERSCHMANN, Micael [e] FREIRE FILHO. João. "Funk carioca: entre a condenação e a aclamação na mídia.". ECOPÓS, v.6, n.2, agosto-dezembro 2003, pp.60-72.

LEMOS, Ronaldo. Tecnobrega: o Pará reinventando o negócio da música. Rio de Janeiro: Aeroplano, 2008.

MACEDO, Káritha. Eis que nasce a baiana: relações entre Carmen Miranda, identidade e estado. Travessias, v. 5, n. 2, 2011. Disponível em: http://erevista.unioeste.br/index.php/travessias/article/view/5602 , acessado em 15/04/2017.

MACHADO, Cacá. $\mathbf{O}$ enigma do homem célebre: ambição e vocação de Ernesto Nazareth. São Paulo: Instituto Moreira Sales, 2007.

MONTEIRO, Marianna. Dança popular: espetáculo e devoção. São Paulo: Editora Terceiro Nome, 2011.

MOURA, Milton. Esses pagodes impertinentes...: algumas reflexões sobre o sofisticado e o vulgar no âmbito da música popular em Salvador. Textos de Cultura e Comunicação, Salvador, v. 36, n. 36, p. 53-66, 1996.

NAPOLITANO, Marcos. A síncope das idéias: a questão da tradição na música popular brasileira. São Paulo: editora da fundação Perseu Abramo, 2007.

NASCIMENTO, Clebemilson. Pagodes baianos: entrelaçando sons, corpos e letras. Salvador: EDUFBA, 2012.

O Estado da Segurança Alimentar e Nutricional no Brasil 2015. Agendas convergentes. FAO-Brasil, outubro de 2015. Disponível em:

https://www.google.com.br/url?sa=t\&rct=j\&q=\&esrc=s\&source= web\&cd=1\&ved=0ahUKEwiZ-

5OW2dHWAhWFHJAKHfSyAqoQFggnMAA\&url=http $\% 3 \mathrm{~A} \% 2$ F\%2Frepositorio.unb.br\%2Fbitstream \%2F10482\%2F21925\%2F1 
\%2FSOFI\%2520Brasil\%25202015.pdf\&usg=AOvVaw2FkC9BY3k kXDZo817ghp9o, acessado em 04/05/2017.

PAIVA, Vânia. Crença e consumo no mercado de música gospel em Alagoas. Trabalho de conclusão de curso. Bacharelado em Ciências Sociais, 2016.

REBHUN, L. A. The heart is unknown country: love in the changing economy of Northeast Brazil. Stanford: Stanford University Press, 1999.

REIS, Alberto Olavo Advincula; OLIVEIRA-MONTEIRO, Nancy Ramacciotti de. Sexualidade e procriação na ótica de jovens de periferias sociais e urbanas. Rev. bras. crescimento desenvolv. hum., São Paulo, v. 17, n. 2, p. 54-63, ago. 2007. Disponível em $<$ http://pepsic.bvsalud.org/scielo.php?script=sci_arttext\&pid=S0 104-12822007000200008\&lng=pt\&nrm=iso $>$ acessos em 01/09/2017.

RODRIGUES, Fernando de Jesus. Economia simbólica da excitação: sobre os circuitos musicais populares nas periferias e o sentido erótico-dançante no tecnobrega e no pagode baiano. Tese de doutorado. Programa de Pós-graduação em Sociologia da Universidade de Brasília (UnB), 2011.

Estruturas sociais do amor e do sexo e as emoções erótico-dançantes no pagode baiano. In: FERNANDES, Dmitri Cerboncini e SANDRONI, Carlos (Orgs.). Música \& Ciências Sociais: para além do descompasso entre arte e ciência. Curitiba: Editora Prismas, 2016a.

Do confraternal ao profissional: periferização urbana e os empreendedores de diversão no circuito de aparelhagens em Belém, Pará. Políticas Culturais em Revista, v. 9, n. 2, p. 535-559, 2016 b.

Mercados musicais-dançantes e periferias: trajetórias individuais e de circuitos de diversão em Salvador e Maceió. Ciências Sociais Unisinos, v. 53, n. 1, p. 8699, 2017. 
Erotismo dançante e as distâncias sociais entre homens e mulheres no Brasil

SALLES, Vicente. A modinha no Grão-Pará: estudo sobre a ambientação e (re) criação da Modinha no Grão-Pará. Belém: Scult/IAP/AATP, 2005.

SANDRONI, Carlos. Feitiço decente: transformações do samba no Rio de Janeiro (1917-1933). Rio de Janeiro: Jorge Zahar Editor, 2001.

SANTOS, Andréa, Laís Barros. "Mercado religioso, periferia e reconfiguração de gênero: a migração dos fiéis e os novos sensos de pertencimento das evangélicas" em: RODRIGUES, Fernando de Jesus (Org.). "Periferias" e economias das simbolizações: lutas por valor humano e mercados culturais. Maceió: Edufal; Imprensa Oficial, 2017.

SEVERIANO, Jairo. Uma história da música popular brasileira: das origens à modernidade. São Paulo: Editora 34, 2008.

SILVA, Expedito Leandro. Do bordel às aparelhagens: a música brega paraense e a cultura popular massiva. Tese (Doutorado em Ciências Sociais) - Pontifícia Universidade Católica de São Paulo, São Paulo, 2009.

VELHO, Gilberto [e] ALVITO, Marcos (orgs). Cidadania e violência. Rio de Janeiro: Editora UFRJ/Editora FGV, 2000.

VELLOSO, Mônica Pimenta. A dança como alma da brasilidade. Paris, Rio de Janeiro e o maxixe. Novo Mundo Mundos Novos, 2007. Disponível em: http://nuevomundo.revues.org/3709 , acessado em 19/04/2017. VIANNA, Hermano. O Mundo Funk Carioca. Rio de Janeiro: Jorge Zahar Editor, [1987] 1997.

TINHORÃO, José Ramos. Domingos Caldas Barbosa: o poeta da viola, da modinha ao lundu. São Paulo: Editora 24, 2004. WINNICOTT, Donald Woods. Natureza humana. Rio de Janeiro: Imago, 1990.

WOUTERS, Cas. Sex and manners: female emancipation in the west 1890-2000. SAGE: London, 2004. 
Informalization: manners e emotions since 1890. SAGE: London, 2007.

Universally applicable criteria for doing figurational process sociology: Seven balances, one triad. Human Figurations, v. 3, n. 1, 2014. Em: http://hdl.handle.net/2027/spo.11217607.0003.106, acessado em 20/04/2017.

ZALUAR, Alba [e] ALVITO, Marcos (orgs). Um século de favela. Rio de Janeiro: Editora FGV, 1997.

\section{Filmografia:}

L'apollonide: os amores da casa de tolerância (L'Apollonide Souvenirs de la Maison Close), França, 2011, 122 min. Direção: Bertrand Bonello.

Depois da chuva (Ame Agaru), Japão e França, 1999, 91 min. Direção: Takashi Koizumi.

Enviado em: 03/05/2017

Aceito em: 16/07/2017 